\title{
PENANGANAN GAGAL JANTUNG DIASTOLIK
}

\author{
Starry H. Rampengan
}

\author{
Bagian Ilmu Penyakit Jantung dan Pembuluh Darah \\ Fakultas Kedokteran Universitas Sam Ratulangi/BLU RSUP Prof. Dr. R.D. Kandou \\ Manado \\ Email: starry8888@yahoo.com
}

\begin{abstract}
Diastolic heart failure (HF) is also referred to as heart failure with normal left ventricular systolic function (normal ejection fraction). The difference between the systolic and diastolic HFs is based on their pathophysiology. In the diastolic HFs, the left ventricular function is normal or slightly impaired. The typical manifestations have an increased filling pressure caused by impaired relaxation and compliance of the left ventricle. The management of diastolic HFs includes antihypertensive treatment, maintenance of the sinus rhythm, prevention of tachycardia, reduction of venous pressure, prevention of myocardial ischemia, and prevention of diabetes mellitus. The aim of the diastolic HFs is: to reduce the progression, to relieve its symptoms, to eliminate exacerbations, and to reduce the mortality. The predisposing factors for the diastolic dysfunction include elderly age, female sex, obesity, coronary artery disease, hypertension, and diabetes mellitus. The European Society of Cardiology specifies therapy in diastolic HFs based on: angiotensin converting enzyme inhibitors, angiotensin receptor blockers, beta-blockers, non-dihydropyridine calcium channel blockers, and diuretics.
\end{abstract}

Keywords: diastolic heart failure, management

\begin{abstract}
Abstrak: Gagal jantung diastolik disebut juga sebagai gagal jantung dengan fungsi sistolik ventrikel kiri yang normal (fraksi ejeksi normal). Perbedaan antara gagal jantung sistolik dan diastolik terletak pada patofisiologinya. Pada gagal jantung diastolik fungsi ventrikel kiri normal atau sedikit menurun. Manifestasi yang timbul disebabkan oleh peningkatan tekanan pengisian yang diakibatkan oleh gangguan relaksasi dan komplains ventrikel kiri. Manajemen gagal jantung diastolik meliputi terapi antihipertensi, pemeliharaan irama sinus, pencegahan takikardi, pengurangan tekanan vena, pencegahan iskemik miokard dan pencegahan diabetes melitus. Tujuan terapi gagal jantung diastolik yaitu mengurangi progresivitas, menghilangkan gejala, mencegah eksaserbasi dan menurunkan angka mortalitas. Faktor predisposisi disfungsi diastolik meliputi usia lanjut, jenis kelamin wanita, obesitas, penyakit jantung koroner, hipertensi, dan diabetes melitus. The European Society of Cardiology mengeluarkan beberapa macam penatalaksanaan gagal jantung diastolik berdasarkan: ACE-inhibitors, angiotensin receptor blocker, beta blocker, non dihydropiridine calcium channel blocker, dan diuretik.
\end{abstract}

Kata kunci: gagal jantung diastolik, penatalaksanaan

Gagal jantung kongestif merupakan salah satu penyebab rawat inap tersering di dunia. Biasanya pasien gagal jantung disertai dengan pembesaran jantung dan penurunan fungsi sistolik, tetapi sekitar $50 \%$ pasien gagal jantung mempunyai fungsi sistolik yang normal atau hanya sedikit terganggu yang didiagnosis dengan gagal jantung diastolik atau disebut juga heart failure with preserved ejection fraction (HFPEF). ${ }^{1,2}$

Pada HFPEF fungsi sistolik ventrikel kiri bisa normal atau sedikit menurun (fraksi ejeksi pada ekokardiografi $\geq 40 \%$ ), 
sedangkan pada gagal jantung sistolik, kontraktilitas dari ventrikel kiri sangat menurun. Pada HFPEF manifestasi klinis muncul karena peningkatan tekanan pengisian yang disebabkan gangguan relaksasi dan komplains ventrikel kiri yang menurun. ${ }^{3,4}$

Perbedaan antara dua jenis gagal jantung ini juga diamati pada tingkat selular. Van Heerebeek et $\mathrm{al}^{3}$ menunjukkan bahwa pada HFPEF sering kali didapatkan elongasi miosit jantung dengan peningkatan resting tone. Kekakuan pada dinding dan penurunan komplians dari miokardium merupakan akibat dari meningkatnya jumlah kolagen pada lapisan interstisial. ${ }^{3,4}$

Curah jantung tidak hanya bergantung pada fraksi ejeksi tetapi juga pada volume diastolik. Pada disfungsi diastolik terjadi disfungsi diastolik ventrikel kiri, menyebabkan peningkatan resistensi pengisian ventrikel kiri dan akhirnya mengakibatkan gagal jantung. Gangguan relaksasi ventrikel dan meningkatnya tahanan pada ventrikel merupakan mekanisme dasar terjadinya disfungsi diastolik. Kardiomiopati hipertrofi merupakan contoh klasik dari gejala gagal jantung dengan fungsi sistolik yang masih sangat baik. ${ }^{4}$

\section{DIAGNOSIS}

Diagnosis HFPEF dapat ditegakkan bila pada pasien didapatkan gejala-gejala khas gagal jantung, pemeriksaan fisik menunjukkan adanya kongesti vena dan kongesti paru atau bahkan edema paru, dan ekokardiografi menunjukkan fraksi ejeksi yang normal atau sedikit menurun. Menurut European Society of Cardiology (ESC), diagnosis gagal jantung diastolik harus memperhatikan tiga hal sebagai berikut: ${ }^{1}$

1. Ada tidaknya gejala gagal jantung kongesti. Intoleransi latihan ialah tanda pertama dari kegagalan diastolik, seperti peningkatan denyut jantung selama latihan memperpendek durasi pengisian ventrikel kiri yang sudah terganggu dan menyebabkan kelebihan tekanan pada sirkulasi pulmonal. Identifikasi bentuk gagal jantung tidak mungkin hanya berdasarkan gejala saja, sehingga diagnosis diferensial harus mencakup beberapa kondisi berikut: a) kondisi kardiovaskular: penyakit jantung iskemik, penyakit jantung katup, kardiomiopati hipertrofi dan restriktif, dan pericarditis konstriktif; b) kondisi non-kardiak: penyakit paru, obesitas, anemia, hiperventilasi, hipertiroidism, dan hipertensi pulmonal.

2. Fungsi sistolik ventrikel kiri yang normal atau hanya sedikit abnormal dengan fraksi ejeksi $>40-50 \%$. Fraksi ejeksi merupakan parameter yang paling penting dalam membedakan gagal jantung sistolik dan diastolik.

3. Gangguan relaksasi, pengisian, serta komplians diastolik dan kekakuan diastolik pada ventrikel kiri.

Parameter di atas terutama dinilai berdasarkan ekokardiografi. Tanda-tanda disfungsi diastolik yang ditemukan pada ekokardiografi antara lain abnormalitas dari fase diastolik di mitral inflow (pada pasien dengan irama sinus normal), profil aliran darah pada vena pulmonalis, serta rasio kecepatan awal pengisian mitral dan kecepatan awal diastolik anulus mitral (E/E') yang diukur dengan ekokardiografi tissue doppler. ${ }^{5}$

Faktor predisposisi dari disfungsi diastolik meliputi usia lanjut, obesitas, hipertensi, dan diabetes melitus. Risiko terjadinya HFPEF juga meningkat pada pasien dengan penyakit arteri koroner selama beberapa tahun, pasien dengan riwayat sindroma koroner akut, dan pasien dengan riwayat miokarditis. Sebagian besar pasien dengan HFPEF yaitu pasien dengan hipertrofi ventrikel kiri yang disebabkan oleh berbagai etiologi: kardiomiopati hipertrofi, aorta stenosis, dan penyakit ginjal kronis dengan komplikasi hipertensi. ${ }^{3}$

Prognosis akan memburuk dengan bertambahnya usia. Sebuah analisis dari beberapa studi menunjukkan bahwa selama periode lima tahun persentase pasien HFPEF yang meninggal $15 \%$ berusia $<50$ tahun, $33 \%$ berusia 50-70 tahun, dan 50\% 
Tabel 1. Karakteristik gagal jantung diastolik dibandingkan gagal jantung sistolik. ${ }^{7}$

\begin{tabular}{lcc}
\hline \multicolumn{1}{c}{ Karakteristik } & Gagal jantung diastolik & Gagal jantung sistolik \\
\hline Klinis & & \\
Gejala (contoh: sesak nafas) & Ya & Ya \\
Kongesti (contoh: edema) & Ya & Ya \\
Aktivasi neurohormonal (contoh: BNP) & Ya & Ya \\
Fungsi dan struktur ventrikel kiri & & \\
Fraksi ejeksi & Normal & Menurun \\
Massa ventrikel kiri & Meningkat & Meningkat \\
Ketebalan relatif dinding & Meningkat & Menurun \\
Volume akhir diastolik & Normal & Meningkat \\
Tekanan akhir diastolik & Meningkat & Meningkat \\
Ukuran atrium kiri & Meningkat & Meningkat \\
Aktifitas & & \\
Kapasitas latihan & Menurun & Menurun \\
Curah jantung & Menurun & Menurun \\
Tekanan akhir diastolik & Meningkat & Meningkat \\
\hline
\end{tabular}

berusia $>70$ tahun. Menurut Aurigemma ${ }^{6}$ kelangsungan hidup pasien dengan HFPEF hanya sedikit lebih lama dibandingkan dengan pasien dengan disfungsi sistolik. Tabel 1 menunjukkan karakteristik gagal jantung diastolik dibandingkan gagal jantung sitolik. ${ }^{7}$

\section{PENATALAKSANAAN}

Pengobatan HFPEF ditujukan untuk menghentikan progresivitas penyakit, meringankan gejala, mencegah eksaserbasi dan mengurangi angka kematian. Kesuksesan pengobatan gagal jantung tergantung pada etiologinya. Ekokardiografi merupakan alat diagnostik utama, banyak tersedia, banyak diproduksi, dan tidak mahal. Hasilnya dilengkapi oleh hasil elektrokardiografi dan foto toraks. ${ }^{7}$

Panduan American College of Cardiology (ACC) dan American Heart Association (AHA) menekankan bahwa pengukuran brain natriuretic peptide (BNP) dan $\mathrm{N}$-terminal pro B-type natriuretic peptide (NT-proBNP) sangat membantu dalam stratifikasi risiko pada pasien dengan disfungsi diastolik dan sistolik ventrikel kiri, meskipun tidak boleh digunakan sebagai penanda keberhasilan pengobatan (rekomendasi kelas IIa). Pernyataan ini berdasarkan fakta bahwa pengukuran BNP untuk memonitor pengobatan tidak bisa dikaitkan dengan penurunan angka kematian. ${ }^{7}$ Obat-obatan seperti angiotensin converting enzyme (ACE) inhibitor, angiotensin receptor blocker (ARBs), beta blockers, aldosterone antagonist, dan diuretik ditetapkan sebagai pengobatan untuk gagal jantung sistolik, tetapi penggunaan obat-obat ini pada HFPEF tidak didukung oleh studi multipel. ${ }^{1,7}$

Menurut panduan dari AHA/ACC, pengobatan dari HFPEF harus meliputi terapi hipertensi, pemeliharaan irama sinus, pencegahan terjadinya takikardia, penurunan tekanan vena, dan pencegahan terjadinya iskemia miokard.,

Terapi kausatif, bila digunakan pada tahap awal penyakit, sebaiknya di tahap A (risiko tinggi terjadinya gagal jantung tanpa adanya gejala) yang paling efektif. Terapi yang efektif pada hipertensi, penyakit arteri koroner, dan diabetes melitus akan menurunkan risiko terjadinya komplikasi lanjut. ${ }^{1,7}$

\section{PENANGANAN HIPERTENSI}

Terapi anti-hipertensi merupakan elemen pengobatan yang paling penting. Diperkirakan hipertensi diderita oleh sekitar $60 \%$ pasien dengan HFPEF. Korelasi erat antara dua penyakit ini mendukung terapi anti-hipertensi yang intensif. Harus diingat bahwa pasien usia lanjut mendominasi kelompok ini dan sangat penting untuk 
menghindari penurunan tekanan darah secara cepat. Hal ini penting karena telah terjadi gangguan fungsi saraf otonom yang mempunyai risiko terjadinya hipertensi postural. Normalisasi tekanan darah sistolik membuat afterload yang lebih rendah sehingga mengurangi beban ventrikel kiri, yang nantinya akan mengakibatkan penurunan volume diastolik ventrikel kiri dan tekanan atrium kiri. Keuntungan tidak langsung dari normalisasi tekanan darah yaitu perbaikan keseimbangan oksigen pada miokardium dengan peningkatan perfusi miokardial dan relaksasi yang lebih cepat. Manfaat tidak langsung didapatkan dari penekanan atau pengurangan hipertrofi ventrikel kiri, dan dari penurunan persentase kolagen pada dinding ventrikel kiri. ${ }^{3,6}$

Pemilihan obat yang akan digunakan sebagai terapi untuk edema paru pada hipertensi harus berdasarkan pada onset kerja obat. Penanganan pasien harus meliputi terapi oksigen, morfin, diuretik intravena, dan glyceryl trinitrate (GTN). Penggunaan diuretik dan GTN secara agresif pada pasien dengan pompa jantung yang jelek akan mengakibatkan hipotensi, yang tentunya dapat berbahaya akibat penurunan cepat dari tekanan pengisian ventrikel kiri dan penurunan curah jantung., 3

Pemilihan obat antihipertensi dengan penggunaan lama pada pasien HFPEF harus memperhatikan peran angiotensin dalam proses terjadinya hipertrofi ventrikel kiri dan perubahan struktural pada dinding ventrikel kiri berkaitan dengan peningkatan kolagen. Dalam memperimbangkan aspek manajemen ini, obat pilihan meliputi $A C E$ inhibitor, AT1 receptor blocker (ARB) dan aldosterone antagonist. ${ }^{3,6}$ Warner et $\mathrm{al}^{8}$ menunjukkan bahwa kapasitas latihan yang terbatas merupakan konsekuensi dari peningkatan tekanan darah, oleh karena itu tujuan dasar dari terapi harus mencegah peningkatan tekanan darah selama latihan.

Studi Losartan Intervention For Endpoint reduction in hypertension (LIFE) ${ }^{9}$ pada kelompok pasien dengan hipertensi dan hipertrofi ventrikel kiri memperlihatkan keberhasilan yang lebih tinggi dari losartan versus atenolol yang ditunjukkan dalam penurunan primary endpoint (kematian akibat kardiovaskular, infark miokard, atau stroke; $P=0,021)$ dan regresi hipertrofi ventrikel kiri yang diukur dengan ekokardiografi $(P<0,0001)$.

Studi Candesartan in Heart failure: assessment of Reduction in Mortality and morbidity-Preserved (CHARM-Preserved $)^{10}$ membandingkan efek candesartan $v s$ plasebo pada kelompok pasien NYHA klas II, III, dan IV dengan fraksi ejeksi $>40 \%$. Dari 3023 pasien, 1514 dipilih secara acak dan diberi terapi candesartan (dosis target 32 mg/hari) sedangkan 1509 diberi plasebo. Primary endpoint ialah kematian karena kardiovaskular atau angka rawat inap karena gagal jantung. Selama periode 36,6 bulan, primary endpoint terjadi pada 333 (22\%) pasien yang diberikan candesartan dan 366 (24\%) pasien yang menerima plasebo $(P=0,051)$. Kematian akibat penyakit kardiovaskular terjadi pada kedua kelompok sebanyak 170 pasien. Angka rawat inap karena gagal jantung lebih sedikit pada kelompok yang diberi candesartan daripada plasebo (230 versus 279, $P=0,017) .{ }^{10}$

Studi lain yang mengevaluasi manfaat terapi ACE inhibitor yaitu studi Perindopril in Elderly People with Chronic Heart Failure $(P E P-C H F){ }^{11}$ Jumlah total 850 pasien usia $\geq 70$ tahun dengan gejala HFPEF yang dipilih secara acak diberi terapi perindopril $4 \mathrm{mg}$ atau plasebo. Primary endpoint meliputi semua sebab kematian dan kejadian rawat inap yang tidak terencana untuk gagal jantung. Rerata lama pemantauan 26,2 bulan. Primary endpoint tampak pada 107 pasien yang diberikan plasebo dan 100 pasien yang diberikan perindopril $(P=0,545)$. Efek terapi perindopril lebih menguntungkan pada tahun awal dilakukan studi. Pada periode ini primary endpoint didapatkan pada $65(15,3 \%)$ pasien dengan plasebo dan $46(10,8 \%)$ pasien dengan perindopril $(P=$ $0,055)$, dan angka rawat inap karena gagal jantung lebih rendah pada kelompok pasien yang diberikan perindopril $(P=0,033)$. Angka kematian pada kedua kelompok 
hampir sama. Perbaikan yang bermakna kelas NYHA terjadi pada pasien yang diberikan perindopril $(P<0,030)$. Terdapat juga peningkatan yang bermakna dalam jarak jalan kaki selama enam menit pada kelompok yang diberikan perindopril $(P=$ 0,011). Pengobatan dengan perindopril tidak mempengaruhi tingkat NT-proBNP. ${ }^{11}$

Berdasarkan hasil-hasil penelitian di atas dapat disimpulkan bahwa terapi farmakologik pada sistem renin-angiotensinaldosteron dapat mengakibatkan peningkatan kapasitas latihan pasien dengan HFPEF, dan mungkin juga menurunkan risiko rawat inap untuk gagal jantung, tetapi tidak mempengaruhi prognosis. Dari hasil studi PEP-CHF dapat disimpulkan bahwa keparahan gagal jantung pada studi populasi tergolong ringan, yang dibuktikan oleh tingkat NT-proBNP (rerata nilai pada kelompok dengan plasebo dan grup dengan perindopril ialah $453 \mathrm{pg} / \mathrm{mL}$ dan 335 $\mathrm{pg} / \mathrm{mL}$ ). Angka komplikasi yang relatif rendah, jauh lebih rendah dari yang diharapkan, juga mendukung hipotesis di atas. Untuk melihat penurunan yang bermakna dari angka kematian pada populasi, ke depannya diperlukan pemantauan yang lebih lama dan memperbanyak jumlah sampel. $^{11,12}$

Studi Valsartan in Diastolic Dysfunction $(V A L I D D)^{12}$ menunjukkan bahwa penurunan tekanan darah dapat meningkatkan fungsi diastolik miokardium pada pasien hipertensi tanpa gagal jantung dan bahwa efek ini tidak tergantung pada jenis anti-hipertensi yang digunakan.

Panduan dari ACC/AHA menempatkan kontrol tekanan darah sistolik dan diastolik sebagai pilihan utama untuk penanganan HFPEF (kelas IA). ${ }^{7}$ Efek dari normalisasi tekanan darah meliputi penurunan tekanan akhir diastolik, penurunan tekanan atrium kiri, perbaikan dari relaksasi yang mengarah ke peningkatan pengisian awal, pengurangan pada iskemia miokard (dengan mengurangi kebutuhan oksigen dan meningkatkan perfusi sebagai hasil dari penurunan tekanan akhir diastolik), pengurangan hipertrofi ventrikel kiri dan menghasilkan pengurangan risiko terjadi atau perburukan dari gagal jantung.

Pada studi Systolic Hypertension in the Elderly Program (SHEP) ${ }^{13}$ menunjukkan bahwa kontrol yang baik dari hipertensi sistolik terisolasi secara bermakna menurunkan risiko terjadinya gagal jantung dan menyebabkan pengurangan indeks massa ventrikel kiri sebanyak 13\%. Pengobatan didasarkan pada chlorthalidone dan atenolol. $^{13,14}$

\section{PEMELIHARAAN IRAMA SINUS DAN PENCEGAHAN TAKIKARDI}

Panduan ACC/AHA menempatkan kontrol irama ventrikel pasien dengan atrial fibrilasi (AF) dan pengembalian irama sinus pada pasien dengan AF pada kelas rekomendasi II dengan tingkat bukti A. ${ }^{7}$

Dalam kondisi fisiologik, denyut jantung meningkat menyebabkan relaksasi dan sedikit menurunkan tekanan diastolik pada ventrikel. ${ }^{15}$

Pada gagal jantung diastolik, takikardi menimbulkan relaksasi yang tertunda dan peningkatan tekanan diastolik. Selain itu, terjadi kontribusi persentase diastolik dalam kaitannya dengan penurunan sistolik melalui peningkatan denyut jantung. Porsi diastolik mencakup hampir $70 \%$ dari siklus jantung pada denyut jantung $60 \mathrm{kali} / \mathrm{menit}$; sekitar $50 \%$ pada denyut jantung 120 kali/menit; dan hanya $40 \%$ pada denyut jantung $180 \mathrm{kali} / \mathrm{menit}$. Oleh karena itu waktu pengisian ventrikel kiri dipersingkat. Penurunan denyut jantung menghasilkan penurunan tekanan pada periode awal dari fase diastolik dengan meningkatkan relaksasi dan meningkatkan waktu pengisian ventrikel kiri, yang akhirnya meningkatkan curah jantung. Waktu perfusi koroner juga meningkat bersamaan dengan menurunnya konsumsi oksigen oleh miokardium dan meningkatkan pasokan darah pada miokardium. Para pakar di ESC merekomendasikan penggunaan beta bloker atau calcium channel blockers (CCB) untuk mengurangi denyut jantung. ${ }^{15}$

Studi Swedish Doppler-echocardiographic $(S W E D I C)^{16}$ meneliti efek penggunaan carvedilol selama enam bulan pada 
97 pasien hipertensi dengan parameter fungsi diastolik pada ekokardiografi. Ditemukan adanya perbaikan yang bermakna dibandingkan dengan placebo pada rasio E/A dari 0,72 ke $0,83(P=$ 0,046). Pada salah satu publikasi sebelumnya ditunjukkan adanya manfaat penggunaan verapamil intravena dengan parameter pengisian ventrikel kiri pada pasien dengan kardiomiopati hipertrofi. ${ }^{16}$

Dengan memperhatikan hubungan dekat antara tekanan pengisian ventrikel kiri dan kapasitas latihan pada pasien, penurunan denyut jantung pada HFPEF harus diprioritaskan. Pada pasien dengan HFPEF, jantung sudah tidak mampu untuk mengambil manfaat dari mekanisme FrankStarling selama latihan atau aktivitas fisik. Pada ventrikel yang kaku, meskipun tekanan pengisian meningkat tetapi tidak dapat meningkatkan volume. Sebagai konsekuensinya terjadi peningkatan tekanan pengisian ventrikel tetapi curah jantung tidak meningkat. Oleh karena itu dengan menurunkan irama ventrikel maka curah jantung dapat ditingkatkan. Gejala ini mungkin dapat dihilangkan dengan pemberian beta bloker dan CCB. Pada Study of Effects of Nebivolol Intervention on Outcomes and Rehospitalization in Seniors With Heart Failure (SENIORS) ${ }^{17}$ nebivolol secara bermakna menurunkan risiko kematian dan angka rawat inap pada dua kelompok pasien yaitu yang dengan gagal jantung dan fraksi ejeksi menurun dan yang dengan fraksi ejeksi normal.

Perbedaan penting pada penanganan kedua jenis gagal jantung terletak pada penggunaan $\mathrm{CCB}$ dihidropiridin, yang bermanfaat untuk terapi pada disfungsi diastolik. CCB dihidropiridin mempunyai efek relaksasi miokardium, juga dapat menurunkan tekanan darah dan denyut jantung. ${ }^{15}$

Peran digitalis dalam peñatalaksanaan HFPEF masih kontroversial, terutama dalam hal mempertahankan irama sinus. Dalam studi Digitalis Investigation Group (DIG) ${ }^{18}$ sebanyak 988 pasien dengan gagal jantung mempunyai fraksi ejeksi $>45 \%$, 492 diantaranya secara acak diberikan digoxin dan 496 diberikan plasebo.
Keuntungan dari penggunaan digitalis pada kelompok ini sama dengan pasien yang mempunyai fraksi ejeksi yang menurun, namun diyakini secara luas bahwa penggunaan digitalis pada HFPEF harus dibatasi untuk pasien dengan AF. Tujuan utama penggunaan obat ini yaitu untuk kontrol irama ventrikel. Digitalis tidak boleh digunakan bila irama sinus masih dapat dipertahankan.

Gangguan pengisian ventrikel kiri pada disfungsi diastolik dapat semakin diperparah oleh irama non-sinus; oleh karena itu menghilangkan aritmia seperti $\mathrm{AF}$ atau atrium flutter merupakan elemen pengobatan yang penting. Bila irama sinus tidak dapat dipertahankan, mungkin dapat dipertimbangkan melakukan ablasi atrioventricular node atau pemasangan pacemaker. $^{18}$

\section{PENURUNAN TEKANAN VENA}

Peningkatan tekanan arteri pulmonal sebanyak $1 \mathrm{mmHg}$ akan mengakibatkan peningkatan $23 \%$ angka kematian dan $13 \%$ angka terjadinya kejadian kardiovaskular. Dengan menurunkan tekanan pulmonal, kapasitas latihan dan prognosis akan meningkat. Kesulitan dalam mengoptimalkan tekanan pengisian ventrikel kiri pada HFPEF disebabkan pasien HFPEF mempunyai kurva tekanan ataupun volume yang berbeda dari kurva fisiologik. Pada pasien HFPEF, meskipun terdapat penurunan tekanan pengisian ventrikel kiri sedikit saja akan menimbulkan penurunan volume diastolik ventrikel kiri yang bermakna, sehingga akhirnya terjadi penurunan curah jantung yang bermakna. Peningkatan tekanan pengisian seringkali gagal secara bermakna mempengaruhi curah jantung tetapi mungkin dapat menyebabkan edema paru. ${ }^{8,19}$

Pasien HFPEF menunjukkan kecenderungan ke arah retensi cairan; oleh karena itu disarankan melakukan pembatasan diet garam dan cairan. Diuretik merupakan andalan untuk pengobatan simtomatik, tetapi mengingat risikonya maka diperlukan kewaspadaan dalam penggunaan diuretik atau nitrat kerja panjang, terutama 
pada fase awal penggunaan obat ini, harus dengan pengawasan ketat dari tenaga medis. Diuretik tidak memengaruhi miokardium secara langsung, sedangkan nitrat meningkatkan kemampuan ventrikel kiri untuk memperbesar volumenya dengan melepaskan nitrogen nitrat. ${ }^{7,15}$

Efek penurunan tekanan vena meliputi menurunkan tekanan ventrikel kiri sehingga meningkatkan fungsi jantung; menurunkan tekanan akhir diastolik ventrikel kiri sehingga mengakibatkan peningkatan kapasitas latihan; dan meningkatkan pasokan oksigen ke miokardium sehingga menghilangkan iskemia.

Pengobatan diatas berisiko terjadinya dehidrasi yang akan mengakibatkan lowoutput syndrome, hipotensi, dan gangguan fungsi ginjal. Dosis obat-obatan yang dapat menyebabkan dehidrasi ini lebih rendah dibandingkan penggunaan pada pasien dengan disfungsi sistolik. Spironolakton merupakan obat yang bekerja multi fungsi dimana memiliki efek sebagai diuretik dan efek untuk menyeimbangkan neurohormonal yang turut memperbaiki struktur ventrikel kiri. ${ }^{9}$

\section{PENCEGAHAN ISKEMIA}

Iskemia miokard merupakan salah satu mekanisme penting yang mendasari FPEF. Oleh karena itu dibenarkan untuk menggunakan obat yang mempunyai efek mengurangi konsumsi oksigen miokardium (beta bloker, CCB, nitrat) dan revaskularisasi untuk meningkatkan pasokan oksigen ke miokardium. ${ }^{18}$

Peningkatan pasokan oksigen ke miokardium menyebabkan meningkatnya relaksasi, menurunnya tekanan akhir diastolik ventrikel kiri, mengurangi risiko terjadinya aritmia jantung, dan menurunkan denyut jantung. ${ }^{11}$

\section{PENGOBATAN LAIN}

Fukuda et al. ${ }^{20}$ meneliti efek statin pada pasien HFPEF yang diterapi dengan beta bloker atau CCB, dan ACE inhibitor atau ARB. Sebanyak 68 pasien diberikan statin dan sisanya 69 pasien tidak diberikan statin. Hasilnya menunjukkan bahwa penggunaan statin mempunyai efek menguntungkan yaitu menurunkan 20\% angka kematian (angka kematian 0,06 vs 0,62, $P$ $=0,005)$. Selain itu, statin mempunyai kecenderungan menurunkan angka rawat inap pasien penyakit kardiovaskular $(P=$ 0,082). Penggunaaan obat lainnya tidak mempunyai efek yang menguntungkan. Efek menguntungkan dari penggunaan statin pada pasien HFPEF tidak hanya karena stabilisasi plak pada arteri koroner, tetapi juga karena statin dapat mengurangi massa ventrikel kiri dan mengurangi fibrosis. Tabel 2 di bawah ini menunjukkan dasar patofiologi dan terapi HFPEF.

Tabel 2. Dasar patofisiologi dan terapi pada HFPEF. ${ }^{7}$

\begin{tabular}{ll}
\hline \multicolumn{1}{c}{ Dasar Patofisiologi } & \multicolumn{1}{c}{ Terapi } \\
\hline Kontrol hipertensi & ACE inhibitor \\
& AT1 receptor blocker \\
& Aldosterone antagonist \\
Menurunkan denyut jantung (pertahankan irama & Beta blocker \\
sinus) & Calcium channel blocker (non-dihydropiridine) \\
Menormalkan kontraksi atrium (fibrilasi atrium) & Digoxin (kontroversial) \\
Mengurangi volume overload (tekanan vena) & Diuretik \\
& Aldosterone antagonist \\
& Restriksi garam dan cairan \\
Pencegahan iskemia & Beta blocker \\
& Calcium channel blocker (non-dihydropiridine) \\
& Nitrat \\
& Revaskularisasi \\
\hline
\end{tabular}




\section{SIMPULAN}

Pada gagal jantung diastolik (HFPEF) ditemukan fungsi sistolik yang normal atau hanya sedikit terganggu. Penanganan gagal jantung diastolik harus dilakukan secara optimal untuk meningkatkan prognosis pasien, yang didasarkan pada:

1. Penanganan kausatif yang meliputi penanganan hipertensi, diabetes melitus tipe II, aritmia (pencegahan takiaritmia dan jika memungkinkan mempertahankan irama sinus), penyakit jantung iskemik, penurunan berat badan, dan pembatasan diet garam.

2. Penanganan simptomatik dengan beta bloker, $\mathrm{CCB}$ non-dihidropiridin, $\mathrm{ACE}$ inhibitor, $A R B$, diuretik, statin, dan antagonis aldosteron.

\section{DAFTAR PUSTAKA}

1. Aurigemma GP. Diastolic heart failure: A common and lethal codition by any name. N Engl J Med. 2006;355:308-10.

2. Grossman W. Defining diastolic dysfunction. Circulation. 2000; 101:2020-1.

3. Dickstein K, Cohen-Solal A, Fillippatos G, McMurray J, Ponikowski P, Poole-Wilson PA, et al. ESC Guidelines for the diagnosis and treatment of acute and chronic heart failure. Eur Heart J. 2008;29:2388-442.

4. Van Heerebeek L, Borbly A, Niessen HW, Bronzwaer JG, Van der Velden J, Stienen GJ, et al. Myocardial structure and function differ in systolic and diastolic heart failure. Circulation. 2006; 113:774-81.

5. Opolski G. Echocardiography parameters in heart failure patients with preserved ejection fraction. Kardiologia. Wroclaw: Urban \& Partner, 2003.

6. Nagueh SF, Appleton CP, Gillebert TC, Marino PN, Oh JK, Smiseth OA, et al. Recommendation for the evaluations of the left ventricular diastolic function by echocardiography. Eur $\mathbf{J}$ Echocardiogr. 2009; 10:165-93.

7. Jessup M, Abraham WT, Casey DE, Feldman AM, Francis GS, Ganiats TG, et al. ACCF/AHA guidelines for the diagnosis and management of heart failure in adult: A report of the American College of Cardiology Foundation/ American Heart Association Task Force on Practice Guidelines. Circulation. 2009;119:1977-2016.

8. Gandhi SK, Powers JC, Nomeir AM, Fowle K, Kitzman DW, Rankin KM, et al. The pathogenesis of acute pulmonary edema associated with hypertension. $\mathrm{N}$ Engl $\mathrm{J}$ Med. 2001;244:17-22.

9. Dahlof B, Devereux RB, Kjedsen SE, Julius S, Beevers G, de Faire U, et al. Cardiovascular morbidity and mortality in the Losartan Intervention for Endpoint Reduction in Hypertension Study (LIFE): A randomised trial againts atenolol. Lancet. 2002;359:995-1003.

10. Yusuf S, Pfeffer MA, Swedberg K, Granger CB, Held P, McMurray JJV, et al. Effects of candesartan in patients with chonic heart failure and preserved left ventricular ejection fraction: The CHARM-Preserved Trial. Lancet. 2003;362: 771-81.

11. Cleland JGF, Tendera M, Adamus J, Freemantle N, Polonski L, Taylor J, et al. The perindopril in elderly people with chronic heart failure (PEP-CHF) study. Eur Heart J. 2006;27:2338-45.

12. Solomon SD, Janardhanan R, Verma A, Bourgoun M, Daley WL, Purkayastha D, et al. Valsartan in Diastolic Dysfunction (VALIDD) Investigators. Effect of angiotensin receptor blockade and antihypertensive drugs on diastolic function in patients with hypertension and diastolic dysfunction: A randomised trial. Lancet, 2007; 369: 2079-2087.

13. Kostis JB, Davis BR, Cutler J, Grimm RH, Berge KG, Cohen JD, et al. Prevention on heart failure by antihypertensive drug treatment in older person with isolated systolic hypertension. SHEP Cooperative Research Group. JAMA. 1997;278:212-6.

14. Ofili EO, Cohen JD, St. Vrain J, Pearson A, Martin TJ, Uy ND, et al. Effect of treatment of isolated systolic hypertension on left ventricular mass. JAMA. 1998; 278-80.

15. Bergstorm A, Adersson B, Edner $M$, 
Nylander E, Persson H, Dahlstrom U. et al. Effect of carvedilol on diastolic dysfunction in patients with diastolic heart failure and preserved systolic function. Result of the Swedish Doppler-echocardiographic study (SWEDIC). Eur J Heart Fail. 2004; 6:453-61.

16. Tendera M, Schneeweiss A, Bartoszewski A, Polonski L, Wodniecki J, Salomon A, et al. The acute response of the left ventricular filling dynamics to intravenous verapamil predicts the changes in exercise tolerance after oral verapamil therapy in patients with hypertrophic cardiomyopathy, Eur Heart J. 1993;14:410-5.

17. Ghio S, Magrini G, Serio A, Klersy C, Fucilli A, Ronaszeki A, et al. SENIORS investigators. Effects of nebivolol in elderly heart failure patients with or without systolic left ventricular dysfunction: Results of the SENIORS echo-cardiographic substudy. Eur Heart J. 2006;27:562-8.

18. The digitalis investigation group. The effect of digoxin on mortality and morbidity in patients with heart failure. N Engl J Med. 1997;336: 525-33.

19. Kramer K, Kirkman P, Kitzman D, Little WC. Flash pulmonary edema: association with hyper-tension and reoccurrence despite coronary revascularization. Am Heart J. 2000;40:451-5.

20. Fukuda H, Sane DC, Brucks S, Little WC. Statin therapy may be associated with lower mortality in patients with diastolic heart failure. A preliminary report. Circulation. 2005;112:357-63. 